\title{
A new species of Linaria sect. Supinae from Sierra de Gredos (Sistema Central mountains, Iberian Peninsula)
}

\section{Modesto Luceño1, Mario Fernández-Mazuecos² \& Pablo Vargas²}

${ }^{1}$ Department of Molecular Biology and Biochemical Engineering. Pablo de Olavide University. Ctra. de Utrera, km. 1. 41013 Seville (Spain).

${ }^{2}$ Real Jardín Botánico (RJB-CSIC). Pza. De Murillo, 2. 28014 Madrid (Spain).

\author{
Correspondencia \\ M.Luceño \\ e-mail: mlucgar@upo.es \\ Recibido: 23 julio 2019 \\ Aceptado: 1 octubre 2019 \\ Publicado on-line: 11 octubre 2019 \\ Editado por: A.V. Pérez-Latorre
}

\begin{abstract}
Linaria vettonica Luceño, Mazuecos \& P. Vargas, a new species of Linaria sect. Supinae, is described. It is a narrow endemic inhabiting the southern hills of the western and central massifs of Sierra de Gredos (Sistema Central mountains, Iberian Peninsula). The five populations found occur on siliceous, sandy soils of Quercus pyrenaica woodland clearings and slopes. L. vettonica can be distinguished from Linaria caesia by the densely glandular-pubescent inflorescence, dark purple corolla and brown seeds with tuberculate disc, and from $L$. aeruginea by its erect fertile stems and dark purple -never blackishcorolla.
\end{abstract}

Key words: Linaria, Sierra de Gredos, narrow endemic, taxonomy, seed micromorphology.

\section{Resumen}

Una especie nueva de Linaria sect. Supinae en la Sierra de Gredos (Sistema Central, Península Ibérica)

Se describe Linaria vettonica Luceño, Mazuecos \& P. Vargas, una nueva especie de Linaria sect. Supinae. Se trata de un endemismo restringido que se distribuye por las vertientes meridionales de los macizos occidental y central de la Sierra de Gredos (Sistema Central, Península Ibérica). Las cinco poblaciones encontradas aparecieron sobre suelos arenosos silíceos en claros y laderas de bosques de Quercus pyrenaica. L. vettonica se distingue de L. caesia por sus inflorescencias densamente glandular-pubescentes, corolas de color púrpura oscuro y semillas marrones con disco ornamentado con numerosos tubérculos; de $L$. aeruginea se distingue por sus tallos fértiles erectos y sus flores de color púrpura oscuro, nunca negruzcas.

Palabras clave: Linaria, sierra de Gredos, endemismo restringido, taxonomía, micromorfología de semillas.

\section{Introduction}

Linaria Mill., with over 200 taxa (species and subspecies), is the most diverse genus of the tribe Antirrhineae (family Plantaginaceae) (Fernández-Mazuecos et al., 2019; Sutton, 1988). A main center of diversity is placed in the Iberian Peninsula, where 54 species were recognised by Flora iberica (Sáez \& Bernal, 2009). In fact, Linaria ranks fifth among the vascular plant genera with the highest numbers of endemic species in Iberia (Buira et al., 2016). The taxonomic complexity of the genus is shown by the fact that several new species and taxonomic rearrangements have been proposed shortly after the publication of the taxonomic account for Flora iberica (Blanca et al., 2017; Blanca et al., 2018; Fernández-Mazuecos et al., 2018; Juan et al., 2018; Vigalondo et al., 2015). The highest complexity is found in Linaria sect. Supinae, a clade that has experienced active 
Quaternary speciation, involving allopatry, floral adaptation to diverse pollinators and hybridisation, among other processes (Blanco-Pastor et al., 2015; Blanco-Pastor \& Vargas, 2013; Blanco-Pastor et al., 2012; Valdés, 1970).

While several narrow endemic species of Linaria sect. Supinae are found in southern Iberia (particularly in Baetic mountains), endemic flowering plants are rare in central Iberia (Vargas \& García, 2008), and this is also true for Linaria. Here we describe a new species of Linaria sect. Supinae subsect. Supinae recently discovered in Sierra de Gredos (Sistema Central mountains, Iberian Peninsula), which is the first narrow endemic species of Linaria found in this mountain range.

\section{Materials and methods}

The following specimens of the new species were collected on the southern slope of Sierra de Gredos (Ávila and Cáceres provinces, Spain; Fig. 1) in 2018-2019 and deposited in the UPOS, MA and MGC herbaria:

ÁVILA: Arenas de San Pedro, San Grilás pathway, 40 11' 29.79 " $\mathrm{N} / 5^{\circ} 10^{\prime}$ ' 9.79 'W, 935 $\mathrm{m}$, sandy slopes on the edge of a forest trail in the Quercus pyrenaica domain, 20-04-2019; R.
Sánchez Villegas (213RSV19bis), M. Luceño, C. Sánchez Benz \& A. Escrig; UPOS12629. CÁCERES: Jerte, Los Infiernos gorge, Los Tres Cerros, 40 $10^{\prime} 6.88^{\prime \prime} \mathrm{N} / 5^{\circ} 55^{\prime} 6.25$ ”'W, $1100 \mathrm{~m}$, sandy slopes on the edge of a forest trail in the Quercus pyrenaica domain, 11-05-2018; $R$. Sánchez-Villegas (119RSV18), F. Estévez, M. Luceño \& M. Sánchez-Villegas; UPOS12630. Idem, Navaconcejo, garganta de las Nogaledas, $40^{\circ} 11^{\prime}$ $13^{\prime \prime} \mathrm{N} / 5^{\circ} 50^{\prime} 11$ 'W, $750-800 \mathrm{~m}$, sandy slopes on the edge of a forest trail in the Quercus pyrenaica domain, VI-2018; F. Estévez; UPOS10757. Idem, Losar de la Vera, El Robledo pathway, $40^{\circ} 7{ }^{\prime} 6.71$ ' $\mathrm{N}$ / $5^{\circ} 35^{\prime} 30.76$ "W, $470 \mathrm{~m}$, sandy slopes on the edge of a forest trail in the Quercus pyrenaica domain, 07-06-2019; R. Sánchez-Villegas (334RSV19), M. Luceño, C. Sánchez Benz, L. Sánchez Benz, J. L. Robles, A. Mariscal \& T. Domínguez; UPOS12631. Idem, Navaconcejo, Casar del Abad, 40 $10^{\prime} 6.88^{\prime \prime} \mathrm{N}$ / $5^{\circ} 55^{\prime} 6.25^{\prime \prime} \mathrm{W}, 1250 \mathrm{~m}$, sandy slopes and rocky shelves on the edge of a forest trail in the Quercus pyrenaica domain, 15-04-2019; R. SánchezVillegas (119RSV19), F. Estévez, M. Luceño \& P. Vargas; UPOS12632. Idem, Navaconcejo, 40 $10^{\circ}$ 13.73 "N / 5 50' 11.23 "W, $770 \mathrm{~m}$, sandy slopes on the edge of a forest trail in the Quercus pyrenaica domain, 05-04-2019; M. Sánchez-Villegas

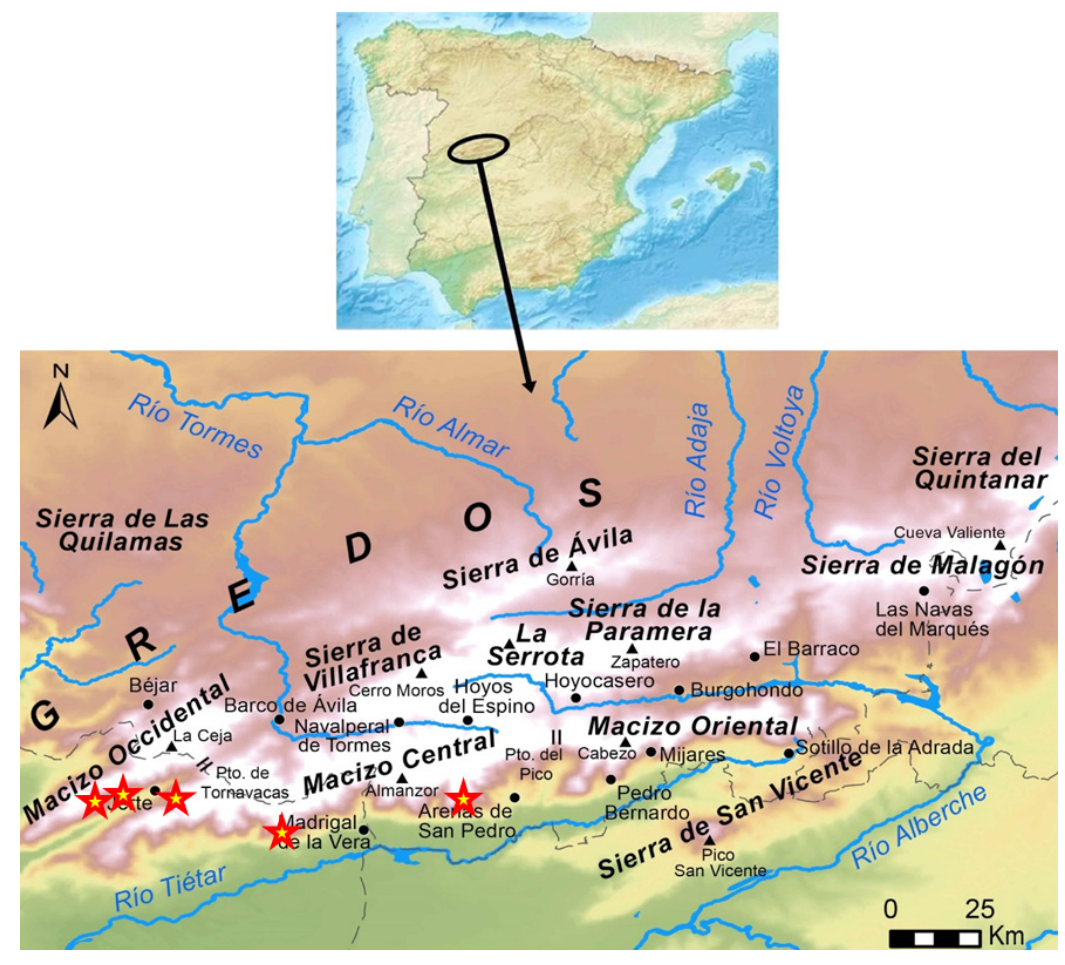

Figure 1. Distribution range of Linaria vettonica in Sierra de Gredos (Sistema Central mountains, Iberian Peninsula). Known localities are shown as stars.

Figura 1. Área de distribución de Linaria vettonica en la Sierra de Gredos (Sistema Central, Península Ibérica). Las localidades conocidas se muestran mediante estrellas. 


\begin{tabular}{|l|l|l|l|}
\hline & L. vettonica & L. caesia & L. aeruginea \\
\hline Fertile stems & $\begin{array}{l}\text { Erect, rarely erect- } \\
\text { ascending }\end{array}$ & Suberect to ascending & $\begin{array}{l}\text { Decumbent to erect- } \\
\text { ascending }\end{array}$ \\
\hline Corolla colour & Dark purple & $\begin{array}{l}\text { Yellow or whitish-yellow with } \\
\text { reddish-brown veins }\end{array}$ & $\begin{array}{l}\text { Purple-blackish (in Gredos), } \\
\text { reddish, reddish-purple, } \\
\text { pink-purple, greyish-purple, } \\
\text { yellow or yellow-orange }\end{array}$ \\
\hline Inflorescence indumentum & $\begin{array}{l}\text { Densely glandular- } \\
\text { pubescent }\end{array}$ & $\begin{array}{l}\text { Glabrous or sparsely } \\
\text { glandular-pubescent }\end{array}$ & Glandular-pubescent \\
\hline Seed colour & Brown & Black & Brown, dark grey or black \\
\hline Seed disc ornamentation & Tuberculate & Smooth, rarely tuberculate & $\begin{array}{l}\text { Tuberculate, smooth or } \\
\text { cristate }\end{array}$ \\
\hline
\end{tabular}

Table 1. Main traits distinguishing Linaria vettonica from $L$. caesia and $L$. aeruginea. $L$. caesia and $L$. aeruginea traits follow Sáez and Bernal (2009).

Tabla 1. Principales caracteres que distinguen Linaria vettonica de L. caesia $y$ L. aeruginea. Los caracteres de L. caesia y L. aeruginea siguen a Sáez and Bernal (2009).

(105MSV19), F. Estévez, M. Luceño \& A. Escrig. UPOS12633, MA939339, MGC89570.

For comparative purposes, we also examined the following specimens of Linaria caesia (Pers.) F. Dietr.:

GUADALAJARA: Olmeda de Cobeta, La Lomilla, 28-05-2016; J. García Muñoz (LM8649); MA908684. MADRID: San Fernando de Henares, Quintana, 11-05-2011; J. M. Martínez Labarga (16702-3/2011-05-11JML) \& $R$. de Pablo; MA872234. Idem, Coslada, between Centro de Transporte and the train track, 25-08-2009; J.
M. Martínez Labarga \& J. Fernández (JGF001); MA798569. SEGOVIA: Aguilafuente, near Molino Cega, 01-05-2002; M. Pérez Valero; MA756383. Idem, Lastras de Cuéllar, La Poza, 04-06-1998; P. Bariego Hernández, J.L. Gutiérrez \& A. Gastón González; MA755787. Idem, San Miguel de Bernuy (Tierra de Pinares), to Navalilla, La Tejera, 16-052016; M. J. Tohá \& V. J. Arán (9041); MA915210. TOLEDO: Ajofrín, between the village and the petrol station, 30-04-2000; M. J. Tohá \& V. J. Arán; MA650290. VALLADOLID: Cigales, 06-06-2007; J. A. Lázaro Bello; MA797053.

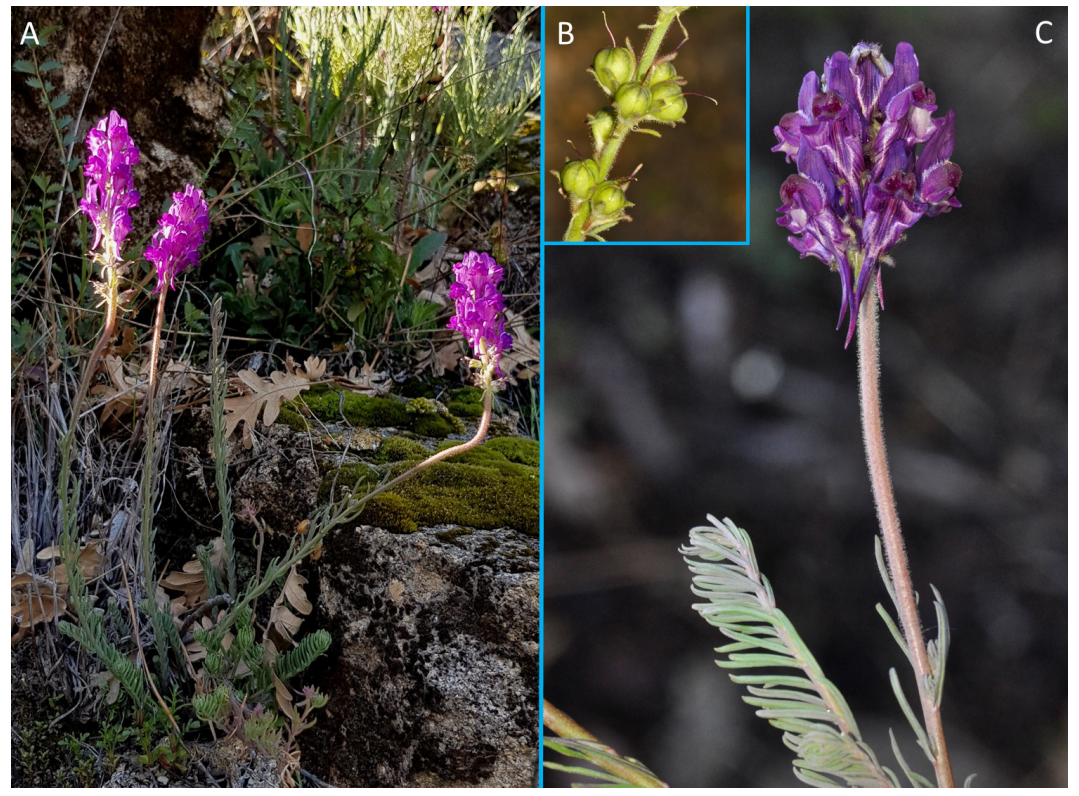

Figure 2. Linaria vettonica. A: habit. B: young capsules. C: sterile stem and young inflorescence.

Figura 2. Linaria vettonica. A: hábito. B: cápsulas jóvenes. C: tallo estéril e inflorescencia joven. 
Methodology and terminology for description of vegetative and reproductive traits followed Sutton (1988). Dry mature seeds were examined by scanning electron microscopy. Seeds were glued to aluminium stubs, sputter-coated with gold using a SCD 004 Sputter Coater (Balzers, Leica) and imaged with a Hitachi S-3000N scanning electron microscope.

\section{Results and discussion}

Linaria vettonica Luceño, Mazuecos \& P. Vargas, sp. nov.

Holotype: CÁCERES: Navaconcejo, $40^{\circ} 11^{\prime}$ $13.73^{\prime \prime} \mathrm{N} / 5^{\circ} 50^{\prime} 11.23$ ”' $770 \mathrm{~m}$, sandy slopes on the edge of a forest trail in the Quercus pyrenaica domain, 05-04-2019; M. Sánchez-Villegas (105MSV19), F. Estévez, M. Luceño \& A. Escrig; UPOS12633.

Isotypes: MA939339; MGC89570.

Diagnosis: Linaria vettonica is similar to $L$. caesia and $L$. aeruginea. It differs from the former by the following features: the inflorescence is densely glandular-pubescent (vs. glabrous or sparsely glandular-pubescent in L. caesia); the corolla is dark purple (vs. yellow or whitish-yellow with reddish-brown veins in $L$. caesia); and seeds are brown (vs. black in L. caesia), with tuberculate disc (vs. smooth or rarely with tuberculate disc in $L$. caesia). It differs from $L$. aeruginea mainly by its erect or, rarely, erect-ascending stems (decumbent to erect-ascending in $L$. aeruginea), and by its deep purple corolla (purple-blackish -in Gredos populations-, reddish, reddish-purple, pink-purple, greyish-purple, yellow or yellow-orange in $L$. aeruginea). (See Table 1).

Description: Biennial or perennial herb, glaucous, glabrous below, densely glandular pubescent in the inflorescence and upper part of fertile stems. Fertile stems up to $80 \mathrm{~cm}$ long, usually erect, rarely erect-ascending, simple or somewhat branched. Sterile stems up to $25 \mathrm{~cm}$, procumbent to ascending. Leaves of fertile stems $10-20$ x c. $1 \mathrm{~mm}$, linear, slightly acute, involute, alternate; leaves of sterile stems similar in size and shape to those of fertile stems, linear or sometimes linear-subulate, slightly acute, involute, alternate. Inflorescence (including basal fruits) up to $15 \mathrm{~cm}$ long, with 15-30 flowers, dense in flower, lax in fruit. Bracts up to $5 \mathrm{~mm}$ long, linear-lanceolate, acute, glandular-pubescent. Pedicels 1-2 mm in flower, 1-3 $\mathrm{mm}$ in fruit, erect, not adnate to inflorescence axis. Calyx lobes, subequal, 3-6 mm long (in the same flower), but the adaxial one c. 2 $\mathrm{mm}$ longer than the other four, c. $1 \mathrm{~mm}$ broad, 4-8 $\mathrm{mm}$ long in fruit, lanceolate to linear-lanceolate, acute, glandular-pubescent mainly on upper parts. Corolla 10-25(28) mm long, 4-8 mm broad, dark purple; tube $3-5 \mathrm{~mm}$ broad, abruptly narrowed into spur; upper (adaxial) lip with two long (c. 3 $\mathrm{mm}$ ) lobes; lower (abaxial) lip densely hairy inside (throat), with white long hairs; spur 8-12 mm, curved, sub-equal or slightly shorter than the rest of the corolla. Style undivided, capitate. Capsule 7-8 mm, globose, glabrous or sometimes sparsely glandular-pubescent on the apex. Seeds 2.6-3.6 $\mathrm{mm}$, orbicular or reniform-orbicular, concavoconvex; hilum narrow; wing 0.8-1.5 mm broad, thin, smooth, not papillate, light brown; disc reniform, covered with prominent tubercles, not papillate, dark brown; periclinal wall of testa cells tabular, verruculate or sometimes reticulate towards the wing margin; anticlinal wall of testa cells straight to angular with conspicuous ridge over junction (Figs. 2, 3 and 4).

Etymology: This species is named after the Vettones, a Celtic people that inhabited Sierra de Gredos in pre-Roman times.

Distribution: southern hills of the western and centrals massifs of Sierra de Gredos (Sistema Central mountains, Iberian Peninsula; Fig. 1).

Habitat: woodland (Quercus pyrenaica Willd.) clearings, slopes, siliceous sandy soils.

Elevational range: $470-1250 \mathrm{~m}$.

Additional specimens examined (Paratypes): ÁVILA: Arenas de San Pedro, San Grilás pathway, $40^{\circ} 11^{\prime} 29.79 " \mathrm{~N} / 5^{\circ} 10^{\prime} 9.79 ” \mathrm{~W}$, $935 \mathrm{~m}$, sandy slopes on the edge of a forest trail in the Quercus pyrenaica domain, 20-04-2019; R. Sánchez Villegas (213RSV19bis), M. Luceño, C. Sánchez Benz \& A. Escrig; UPOS12629. CÁCERES: Navaconcejo, Casar del Abad, 40 10' 6.88 ” N / 5 55' 6.25”'W, $1250 \mathrm{~m}$, sandy hillsides on granite rocks, clearings of Quercus pyrenaica woodlands, 15-04-2019; $R$. Sánchez-Villegas (119RSV19), F. Estévez, M. Luceño \& P. Vargas; UPOS12632. Idem, Navaconcejo, garganta de las Nogaledas, $40^{\circ} 11^{\prime} 13^{\prime \prime} \mathrm{N} / 5^{\circ} 50^{\prime} 11^{\prime \prime} \mathrm{W}, 750-800 \mathrm{~m}$, sandy slopes on the edge of a forest trail in the Quercus pyrenaica domain, VI-2018; F. Estévez; UPOS10757. Idem, Jerte, Los Infiernos gorge, Los Tres Cerros, 40 10' 6.88'N / 5० 55' 6.25”'W, $1100 \mathrm{~m}$, sandy slopes on the edge of a forest trail in the Quercus pyrenaica domain, 11-05-2018; R. Sánchez-Villegas (119RSV18), F. Estévez, M. Luceño \& M. Sánchez-Villegas; UPOS12630. Idem, Losar de la Vera, El Robledo pathway, $40^{\circ} 77^{\prime} 6.71$ ' $\mathrm{N}$ / $5^{\circ} 35^{\prime} 30.76$ ”'W, $470 \mathrm{~m}$, sandy slopes on the edge of a forest trail in the Quercus piyrenaica domain, 07-06-2019; R. Sánchez-Villegas (334RSV19), M. Luceño, C. Sánchez Benz, L. Sánchez Benz, J. L. Robles, A. Mariscal \& T. Domínguez; UPOS12631. 


\section{Key to species of Linaria in Sierra de Gredos}

1. Corolla more than $33 \mathrm{~mm}$ long .......L. triornithophora

- Corolla up to $30 \mathrm{~mm}$ long .................................... 2

2. Corolla completely yellow or whitish-yellow .......... 3

- Corolla predominantly or completely blue, violet, pink, purple, white or blackish .................................... 6

3. Stigma bifid ........................................... L. spartea

- Stigma undivided, capitate ................................... 4

4. Annual herb; fertile stems erect; corolla up to $8(11)$

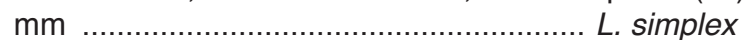

- Biennial or perennial herbs, rarely annual; fertile stems frequently ascending; corolla (9) $10-30 \mathrm{~mm}$..

5. Seeds without encircling wing, or with wing up to $0.2(0.4) \mathrm{mm}$; plants densely glandular-pubescent at least in the inflorescence L. saxatilis

- Seeds with prominent encircling wing 0.4-0.9 mm; plants glabrous except for the sparse presence of glandular hairs in the inflorescence ........... L. caesia

6 Corolla pure white with violet veins ............ L. nivea

- Corolla predominantly or completely blue, violet, pink, purple or blackish ... 7

7. Corolla up to $7 \mathrm{~mm}$ long, blue ............................. 8

- Corolla at least $10 \mathrm{~mm}$ long, blue, violet, pink, purple or blackish
8. Spur up to $1 \mathrm{~mm}$, straight or somewhat curved ........ L. micrantha

- Spur 1.5-3 mm, strongly curved ............ L. arvensis

9. Stigma emarginate or bifid; spur more or less perpendicular to inflorescence axis; seeds trigonousreniform, without encircling wing 10

- Stigma undivided; spur more or less parallel to inflorescence axis; seeds discoid, with prominent encircling wing 11

10.Stigma distinctly bifid; corolla usually occluded by the lower lip (palate); palate with a small yellow spot .....

L. incarnata

- Stigma emarginate; corolla conspicuously openthroated through a pore; palate without a yellow spot L. elegans

11. Lower lip of the corolla spotted with violet

L. amethystea

- Palate not spotted with violet ... 12

12. Fertile stems decumbent to ascending; corolla singlecoloured, very dark (purple-blackish)

L. aeruginea subsp. aeruginea

- Fertile stems decumbent, ascending or erect; if decumbent, corolla two-coloured, otherwise single coloured; corolla predominantly blue, violet, pink or purple, never blackish 13

13. Fertile stems up to $80 \mathrm{~cm}$, usually erect, rarely erect-
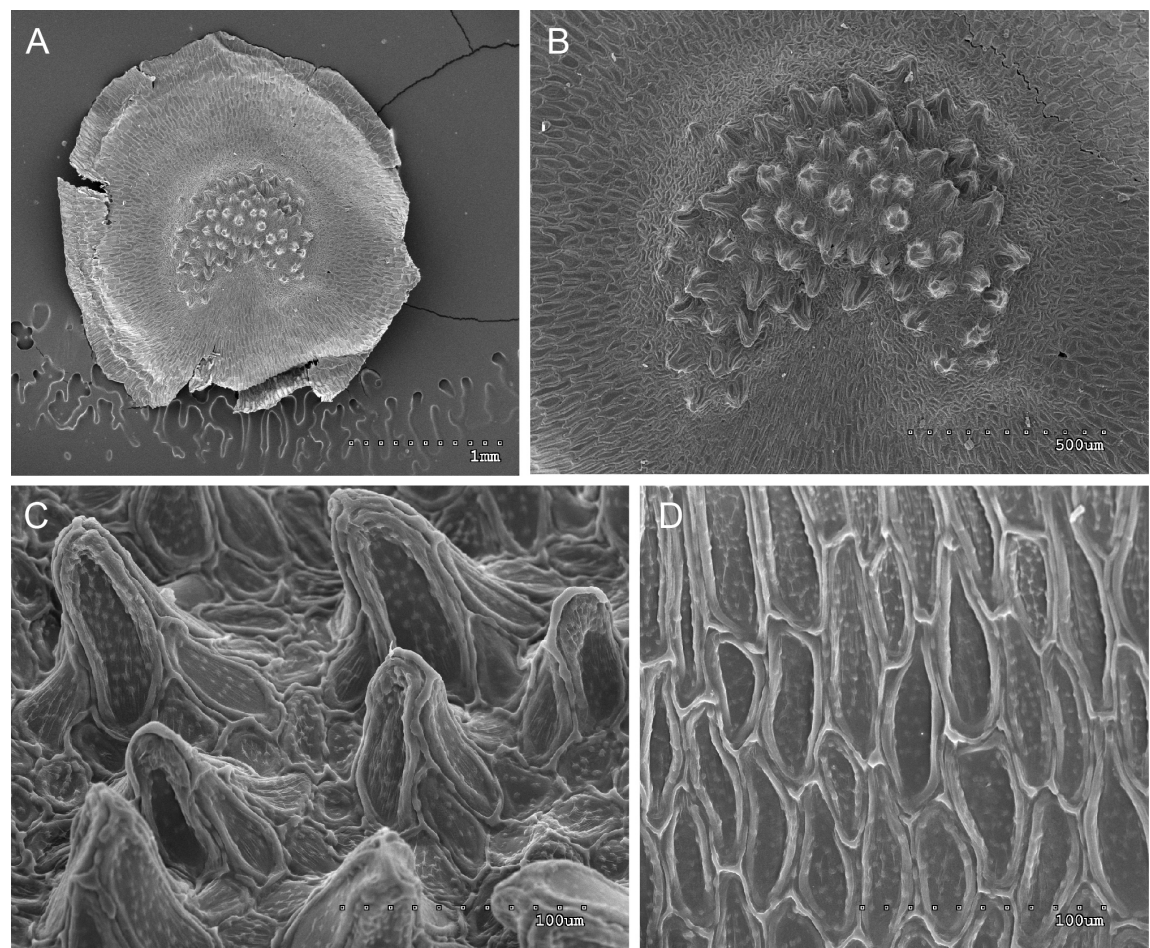

Figure 4. Scanning electron micrographs of Linaria vettonica seeds. A: convex face of seed with tuberculate disc and smooth wing. B: tuberculate disc. C: disc tubercles with verruculate testa cells. D: verruculate testa cells of wing. Micrographs by Yolanda Ruiz.

Figura 4. Fotografías de microscopía electrónica de barrido de semillas de Linaria vettonica. A: cara convexa de una semilla con disco tuberculado y ala lisa. B: disco tuberculado. C: tubérculos del disco con células verruculadas de la testa. D: células verruculadas de la testa del ala. Fotografías de Yolanda Ruiz. 


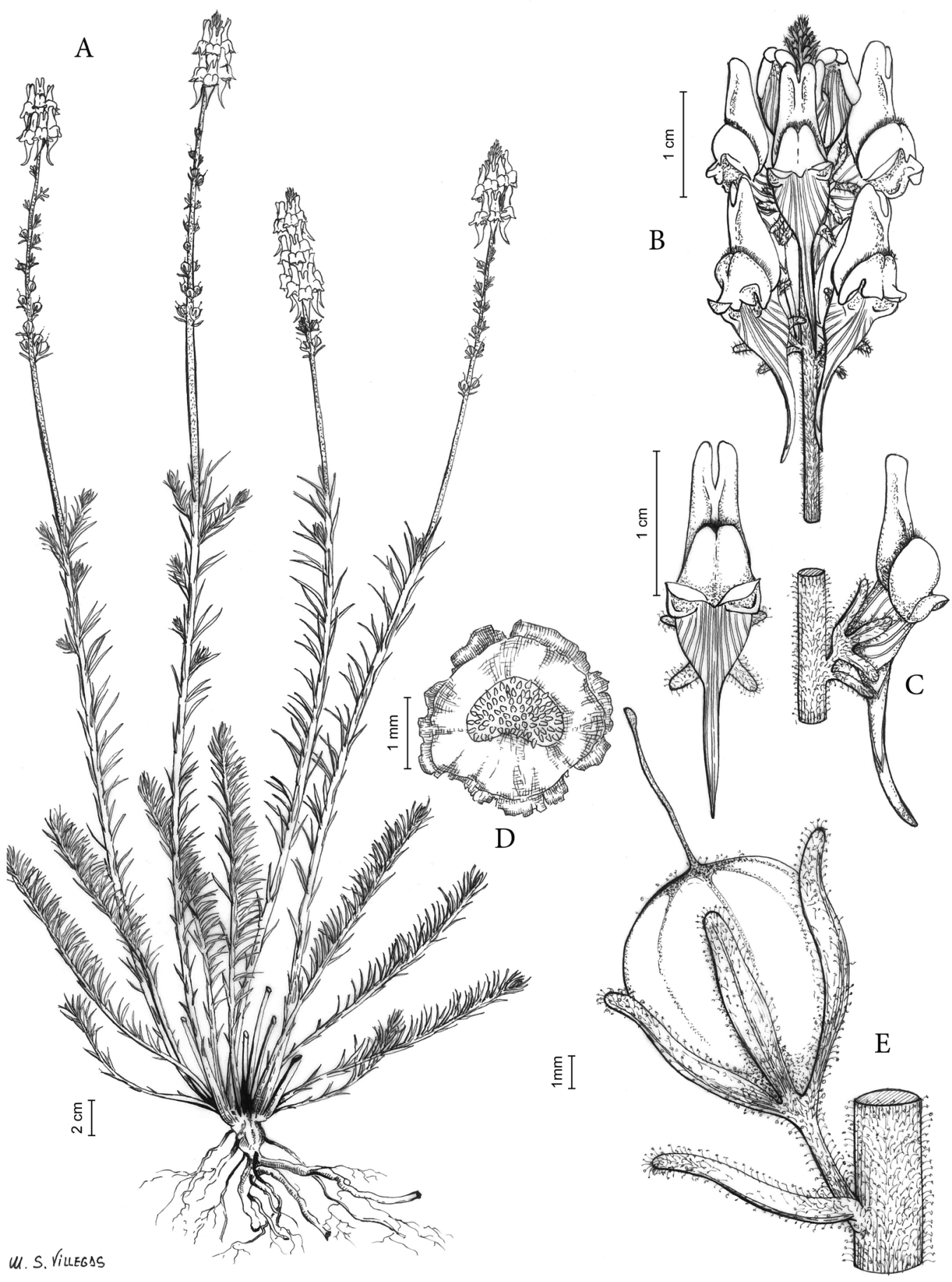

Figure 3. Linaria vettonica. A: habit. B: inflorescence. C: frontal and lateral view of the flower. D: seed. E: capsule. Drawn by Manuel Sánchez-Villegas from the holotype (UPOS12633).

Figura 3. Linaria vettonica. A: porte. B: inflorescencia. C: vista frontal y lateral de una flor. D: semilla. E: cápsula. Dibujado por Manuel Sánchez-Villegas a partir del holotipo (UPOS12633). 
ascending; inflorescence and upper part of fertile stems densely glandular-pubescent; corolla singlecoloured, from medium purple tube and spur to dark purple palate; seed disc covered with prominent tubercles .............................................. L. vettonica

- Fertile stems up to 25(35) cm, decumbent or ascending; inflorescence and upper part of fertile stems glabrous or very sparsely glandular-pubescent; corolla blue or violet with yellow or orange spot on the palate, rarely white; seeds with smooth disc, rarely with low tubercles L. alpina subsp. alpina

\section{Acknowledgements}

The discovery of Linaria vettonica would not have been possible without the work of the group of enthusiasts that participating in the field tasks for the elaboration of the complete floristic catalogue of Sierra de Gredos. The first known populations of the species were sighted in Valle del Jerte by our friend Fernando Estévez, environmental worker in the Garganta de los Infiernos Natural Reserve, who has a deep knowledge of the flora of his home region. Subsequently, another population was found during an excursion in the municipality of Arenas de San Pedro by the sisters Cecilia and Lea Sánchez Benz, together with Blanca Martín, Israel Álvarez and José Luis Robles, all of whom are good friends and passionate about the flora of Gredos. Already this year, we learnt of the existence of another population in the surroundings of Losar de la Vera by the tenacious plant enthusiast and author of the florula of said municipality, Ángel Mariscal. We want to express our sincerest gratitude to all of them. Thanks also to the brothers Manuel and Rogelio Sánchez-Villegas, to whom we owe most of the work of collecting and processing the samples. Immersed in the compulsory and unpleasant university exams, they have been unable to participate actively in the preparation of this work. We thank Yolanda Ruiz (Servicio de Microscopía Electrónica de Barrido, Real Jardín Botánico) for her technical support with scanning electron microscopy. We also owe a debt of gratitude to the staff of the Sierra de Gredos Regional Park, especially to Director Nicolás González, for facilitating the administrative procedures necessary to study the flora of our beloved Sierra. In the same way, we appreciate the support provided by the Dirección General de Medio Ambiente of the Junta de Extremadura. Finaly we thank the two reviewers for the work done to improve this article.

\section{References}

Blanca, G., Cueto, M., \& Fuentes, J. (2017). Linaria becerrae (Plantaginaceae), a new endemic species from the southern Spain, and remarks on what Linaria salzmannii is and is not. Phytotaxa, 298(3), 261-268. http://dx.doi.org/10.11646/phytotaxa.298.3.5

Blanca, G., Cueto, M., Fuentes, J., Sáez, L., \& Tarifa, R. (2018). Linaria qartobensis sp. nov. (Plantaginaceae) from the southern Iberian Peninsula. Nord. J. Bot., 36(8), e01914. https://doi.org/10.1111/njb.01914

Blanco-Pastor, J. L., Ornosa, C., Romero, D., Liberal, I. M., Gómez, J. M., \& Vargas, P. (2015). Bees explain floral variation in a recent radiation of Linaria. J. Evolution. Biol., 28(4), 851-863. https://doi. org/10.1111/jeb.12609

Blanco-Pastor, J. L., \& Vargas, P. (2013). Autecological traits determined two evolutionary strategies in Mediterranean plants during the Quaternary: low differentiation and range expansion versus geographical speciation in Linaria. Mol. Ecol., 22(22), 5651-5668. https://doi.org/10.1111/mec.12518

Blanco-Pastor, J. L., Vargas, P., \& Pfeil, B. E. (2012). Coalescent simulations reveal hybridization and incomplete lineage sorting in Mediterranean Linaria. PLOS ONE, 7(6), e39089. https://doi.org/10.1371/ journal.pone.0039089

Buira, A., Aedo, C., \& Medina, L. (2016). Spatial patterns of the Iberian and Balearic endemic vascular flora. Biodivers. Conserv., 26(2), 479-508. https://doi. org/10.1007/s10531-016-1254-z

Fernández-Mazuecos, M., Ferrer-Gallego, P. P., Miguel, M., Glover, B. J., \& Sáez, L. (2018). A synopsis of the Iberian clade of Linaria subsect. Versicolores (Antirrhineae, Plantaginaceae) based on integrative taxonomy. Plant Syst. Evol., 304(7), 871-884. https:// doi.org/10.1007/s00606-018-1517-0

Fernández-Mazuecos, M., Blanco-Pastor, J. L., Juan, A., Carnicero, P., Forrest, A., Alarcón, M., Vargas, P., \& Glover, B. J. (2019). Macroevolutionary dynamics of nectar spurs, a key evolutionary innovation. New Phytol., 222(2), 1123-1138. https://doi.org/10.1111/ nph.15654

Juan, A., Blanca, G., Cueto, M., Fuentes, J., \& Sáez, L. (2018). Linaria argillicola (Plantaginaceae), a new species of $L$. sect. Supinae from the southern Iberian Peninsula. Phytotaxa, 343(2), 127-138. http://dx.doi. org/10.11646/phytotaxa.343.2.3

Sáez, L., \& Bernal, M. (2009). Linaria Mill. In S. Castroviejo, A. Herrero, C. Benedí, E. Rico, \& J. Güemes (Eds.), Flora iberica XIII (Plantaginaceae Scrophulariaceae) (pp. 232-324). Madrid: CSIC.

Sutton, D. A. (1988). A revision of the tribe Antirrhineae. Oxford: Oxford University Press.

Valdés, B. (1970). Revisión de las especies europeas de Linaria con semillas aladas. An. Univ. Hipalense., 7, 1-288.

Vargas, P., \& García, B. (2008). Plant endemics to Sierra de Gredos (central Spain): taxonomic, distributional, and evolutionary aspects. Anales Jard. Bot. Madrid, 65(2), 353-366. https://doi.org/10.3989/ajbm.2008. v65.i2.298

Vigalondo, B., Fernández-Mazuecos, M., Vargas, P., \& Sáez, L. (2015). Unmasking cryptic species: morphometric and phylogenetic analyses of the Ibero-North African Linaria incarnata complex. Bot. J. Linn. Soc., 177(3), 395-417. https://doi.org/10.1111/ boj.12251 